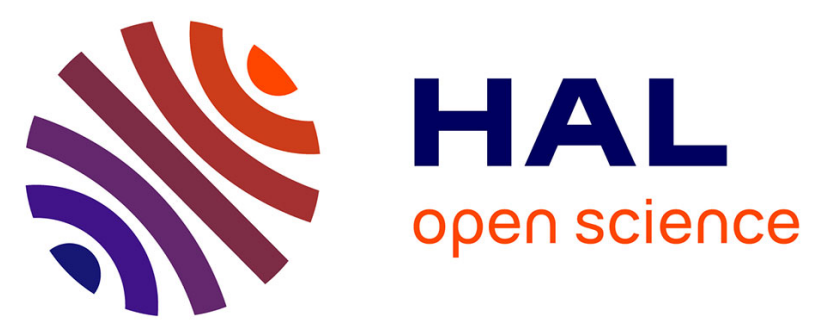

\title{
Efficient synthesis of 3-hydroxymethylated cis- and trans- cyclobutane b-amino acids using an intramolecular photocycloaddition strategy
}

\author{
Aurélie Mondiere, Runhui Peng, Roland Remuson, D.J. Aitken
}

\section{To cite this version:}

Aurélie Mondiere, Runhui Peng, Roland Remuson, D.J. Aitken. Efficient synthesis of 3hydroxymethylated cis- and trans- cyclobutane b-amino acids using an intramolecular photocycloaddition strategy. Tetrahedron, 2008, 64, pp.1088-1093. 10.1016/j.tet.2007.11.021 . hal-00204404

\author{
HAL Id: hal-00204404 \\ https://hal.science/hal-00204404
}

Submitted on 14 Jan 2008

HAL is a multi-disciplinary open access archive for the deposit and dissemination of scientific research documents, whether they are published or not. The documents may come from teaching and research institutions in France or abroad, or from public or private research centers.
L'archive ouverte pluridisciplinaire HAL, est destinée au dépôt et à la diffusion de documents scientifiques de niveau recherche, publiés ou non, émanant des établissements d'enseignement et de recherche français ou étrangers, des laboratoires publics ou privés. 


\title{
Efficient synthesis of 3-hydroxymethylated cis- and trans-cyclobutane $\beta$-amino acids using an intramolecular photocycloaddition strategy
}

\author{
Aurélie Mondière ${ }^{\mathrm{a}}$, Runhui Peng ${ }^{\mathrm{a}}$, Roland Remuson ${ }^{\mathrm{a}, *}$, David J. Aitken ${ }^{\mathrm{a}, \mathrm{b}, *}$ \\ ${ }^{\text {a }}$ Laboratoire SEESIB (UMR 6504-CNRS), Département de Chimie, Université Blaise Pascal-Clermont-Ferrand II, \\ 24 avenue des Landais, 63177 Aubière cedex, France \\ ${ }^{\mathrm{b}}$ Laboratoire de Synthèse Organique et Méthodologie, ICMMO (UMR 8182-CNRS), Bât. 420, Université Paris-Sud 11, \\ 15 rue Georges Clemenceau, 91405 Orsay cedex, France
}

\begin{abstract}
Uracil bearing a tethered allyl alcohol appendage at $\mathrm{N} 1$ undergoes a [2+2] photocycloaddition reaction to provide a single tricyclic adduct in high yield. This compound is transformed in one step into a cis-cyclobutane $\beta$-amino acid bearing a 3-hydroxymethyl group. Through appropriate functionalization and epimerization, the trans isomer is obtained therefrom in only three further steps.
\end{abstract}

\section{Introduction}

$\beta$-Amino acids, and the various peptide structures which include them, often possess interesting structural and biological properties which are complementary to those of their more abundant $\alpha$-amino acid congeners. ${ }^{1}$ The controlled preparation of $\beta$-amino acids is therefore of considerable importance for synthetic chemists. ${ }^{2}$ Since a significant part of the interest in these compounds derives from their ability to adopt and impose marked conformational preferences, there has been a particular focus on alicyclic $\beta$-amino acids and peptide derivatives thereof. ${ }^{3,4}$ Thus, synthetic efforts have been devoted to derivatives of cyclohexane, ${ }^{5}$ cyclopentane, ${ }^{6}$ and cyclopropane ${ }^{7}$ $\beta$-amino acids, although a number of more elaborate carbocyclic scaffolds have also been studied. ${ }^{8}$

Cyclobutane $\beta$-amino acids-more formally, 2-amino-1cyclobutanecarboxylic acids (ACBAs) optionally bearing

\footnotetext{
* Corresponding authors.

E-mail addresses: roland.remuson@univ-bpclermont.fr (R. Remuson), david.aitken@u-psud.fr (D.J. Aitken).
}

ring substituents - should clearly play a significant role in this field, but until now very little study has been made of these carbocycles. ${ }^{9,10}$ This can be partly explained by the paucity of convenient synthetic methods giving access to these building blocks. Only a few synthetic strategies for the preparation of ACBAs have been disclosed. Kennewell et al. ${ }^{11}$ showed that meso-1,2-cyclobutanedicarboxylic acid derivatives could be desymmetrized with one of the functions being transformed into an amine, thus providing access to racemic cis-ACBA. Two enantioselective versions of this approach have been described, by the groups of Ortuño et al. ${ }^{12}$ and Bolm et al. ${ }^{13}$ Until very recently, only racemic syntheses of trans-ACBA had been described, via analogous desymmetrization of the racemic trans-diacid. ${ }^{11,14}$

Ring-substituted ACBAs are rare, and the available synthetic methods lack selectivity and/or generality. ACBAs bearing simple hydrocarbon moieties (alkyl, phenyl, and methylene) at the $\mathrm{C} 3 \mathrm{and} /$ or $\mathrm{C} 4$ position have been described, ${ }^{6 \mathrm{c}, 15}$ while a novel acyl nitrene insertion reaction has provided an isolated entry to 3-hydroxy-ACBAs. ${ }^{16}$ In earlier work, Brannock et al. ${ }^{17}$ prepared a series of $\mathrm{N}, \mathrm{N}$-dialkylated 3,3dialkyl-ACBA esters via a thermal $[2+2]$ cycloaddition 
between enamines and acrylates, although these reactions required harsh conditions and were bereft of stereoselectivity. This approach for the construction of ACBAs has been adapted to give related derivatives, usually under milder conditions. ${ }^{18}$ Interestingly, fully functionalized derivatives of 4-hydroxymethylated cis- and trans-ACBA have been prepared via photopyridones. ${ }^{19}$

We recently demonstrated the utility of a $[2+2]$ photocycloaddition reaction between uracil and ethylene as a rapid and simple entry to cis-ACBA. ${ }^{20}$ Use of a chiral uracil derivative provided access to enantiomerically pure materials, ${ }^{21}$ and these were epimerized in a five-step procedure to establish the first access to trans-ACBA in enantiomerically pure form. ${ }^{21 a}$ In an extension of this photochemical approach, using a series of 5- or 6-substituted uracils, the corresponding 1- and 2-substituted cis-ACBAs were prepared, ${ }^{22}$ including the 1-hydroxymethylated compound.

We wished to further extend this methodology to the preparation of the hitherto unknown 3-hydroxymethyl-ACBA. The particular interest of the primary alcohol substituent lies in its wide potential for grafting of (or transformation into) other side chain entities. In intermolecular $[2+2]$ photocycloadditions with unsymmetrical partners, the possibility of the formation of regioisomers and stereoisomers arises, and in many cases product mixtures are formed. ${ }^{23}$ An intramolecular process is generally much more selective, and indeed a few examples have been described, which involve uracil dervatives. ${ }^{24}$ In consequence, we decided to investigate the reactivity of a uracil bearing a cleavable tether at N1, which would deliver the equivalent of allyl alcohol in an intramolecular fashion (Fig. 1).

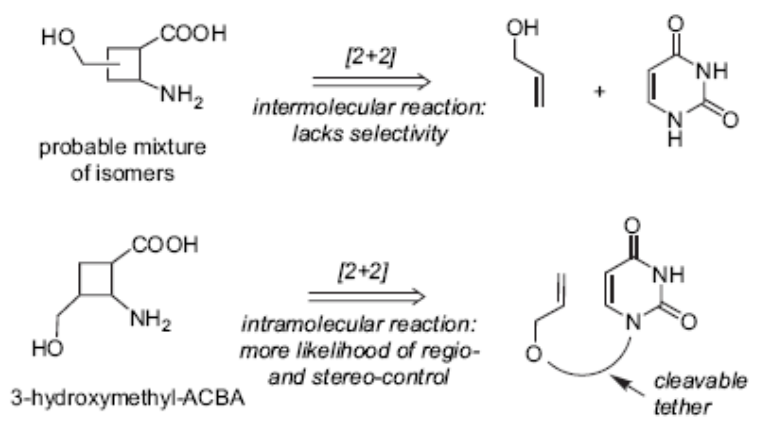

Figure 1. Retrosynthetic analysis.

\section{Results and discussion}

\subsection{Preparation of the cis-cyclobutane $\beta$-amino acid}

We selected to study 1-(allyloxymethyl)uracil 1 . This compound, first described by Ozerov et al., ${ }^{25}$ was conveniently prepared by selective N1-alkylation of uracil using chloromethyl allyl ether ${ }^{26}$ in the presence of cesium iodide and $\mathrm{N}, \mathrm{O}$-bistrimethylsilylacetamide (BSA) in an adaptation of Pederson's procedure ${ }^{27}$ (Scheme 1). A small amount of the
N1,N3-dialkylated material 2 was the only by-product, and was easily separated by filtration.

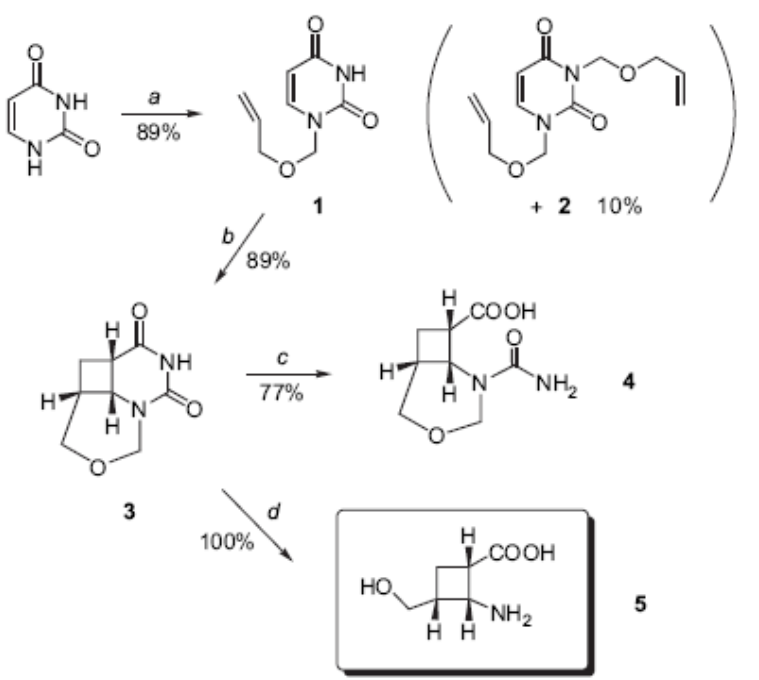

Scheme 1. Reagents and conditions: (a) $\mathrm{CH}_{2}=\mathrm{CHCH}_{2} \mathrm{OCH}_{2} \mathrm{Cl}$, BSA, CsI, $\mathrm{CH}_{2} \mathrm{Cl}_{2} \mathrm{rt}, 4$ h. (b) $h \nu$, acetone, Pyrex, rt, 4 h. (c) $0.5 \mathrm{M} \mathrm{NaOH}$, rt, 18 h. (d) $1 \mathrm{M} \mathrm{NaOH}, 80^{\circ} \mathrm{C}, 10 \mathrm{~h}$, then $1 \mathrm{M} \mathrm{HCl}$.

Compound 1 was subjected to $[2+2]$ photocycloaddition reaction conditions (Scheme 1). A solution of 1 in acetone was irradiated with a $400 \mathrm{~W}$ medium-pressure $\mathrm{Hg}$ vapor lamp fitted with a Pyrex filter under argon for $4 \mathrm{~h}$. In these conditions, the tricyclic cyclobutane adduct 3 was obtained as a single product in $89 \%$ isolated yield. ${ }^{28}$ In alternative reaction conditions, using a quartz reaction vessel and acetonitrile as the solvent, 3 was produced along with several by-products and its isolated yield was lower $(66 \%)$. The structure of compound 3 was determined by $1 \mathrm{D}$ and 2D NMR experiments. The relative stereochemistry was attributed by comparison of NMR spectral data with those of related compounds ${ }^{24 a}$ and supported by NOE observations. An all-cis configuration was thus assigned for $\mathbf{3}$, which had therefore been formed with complete regio- and stereo-chemical selectivities.

Next, the controlled degradation of the heterocyclic rings was undertaken. It was hoped that subjecting 3 to acidic conditions would induce oxazine ring opening via an intermediate $N$-acyl iminium, which might then be hydrolyzed. ${ }^{29}$ In the event, treatment of $\mathbf{3}$ with TFA or $\mathrm{HCl}$ yielded only unreacted starting material. Other attempts to open the oxazine ring of $\mathbf{3}$ using $\mathrm{TMSI}^{30}$ or $\mathrm{BBr}_{3}{ }^{31}$ also failed.

We therefore turned our attention to the dihydrouracil ring. Our recent work on cyclobutane dihydrouracil adducts had shown that treatment with $\mathrm{NaOH}$ in mild conditions can effect selective $\mathrm{N} 3-\mathrm{C} 4$ bond cleavage to provide the corresponding cyclobutane $\beta$-urea acids. ${ }^{20-22}$ Indeed, overnight treatment of 3 with $0.5 \mathrm{M} \mathrm{NaOH}$ (6 equiv) at room temperature furnished compound 4 in $77 \%$ yield (Scheme 1). Previously, it had been noted that in more strongly basic conditions, dihydrouracils can be converted directly into $\beta$-amino acids. ${ }^{32}$ This appeared a more attractive prospect, since we felt that removal of 
the acyl group from the nitrogen atom should make acidmediated oxazine ring opening easier. In the event, treatment of 3 with a $1 \mathrm{M}$ solution of $\mathrm{NaOH}$ at $80^{\circ} \mathrm{C}$ for $10 \mathrm{~h}$ followed by neutralization and passage through acidic anion exchange resin led directly to the target cyclobutane $\beta$-amino acid $\mathbf{5}$ in quantitative yield (Scheme 1). The probable sequence of events for this last step is presented in Scheme 2.
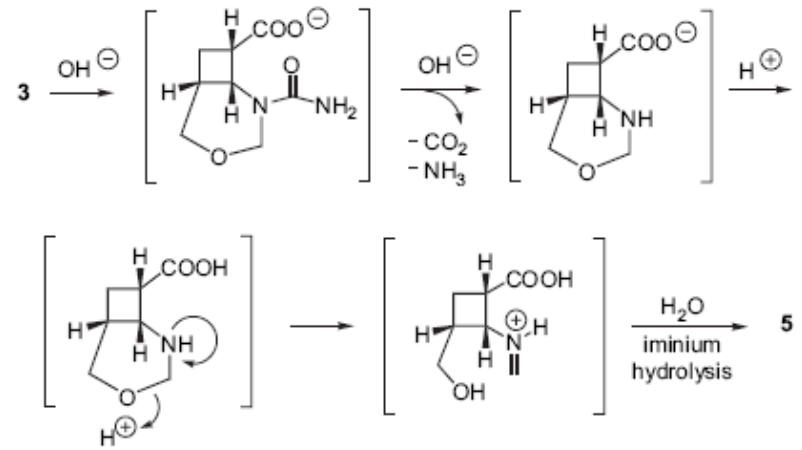

Scheme 2. Proposed sequence of events in the transformation of $\mathbf{3}$ into $\mathbf{5}$.

The new cis-cyclobutane $\beta$-amino acid $\mathbf{5}$ was thus obtained in a very efficient and selective three-step process from uracil (79\% overall yield). It was of interest to note that $\mathbf{5}$ was only moderately stable in aqueous solution, degrading over a period of hours at room temperature. A similar phenomenon has been observed for the parent $\beta$-amino acid and can be imputed to an irreversible 'push-pull' induced ring opening process. ${ }^{33}$

\subsection{Preparation of the trans-cyclobutane $\beta$-amino acid}

With the cis- $\beta$-amino acid $\mathbf{5}$ in hand, we next investigated its controlled epimerization at $\mathrm{Cl}$ in order to gain entry to the trans isomer (Scheme 3). Initially, protection of the amine function of $\mathbf{5}$ was necessary in order to suppress material loss through the ring opening phenomenon. Treatment of $\mathbf{5}$ with $\mathrm{Boc}_{2} \mathrm{O}$ in standard conditions gave the tert-butyl carbamate 6 in only moderate yield $(45 \%)$, presumably due to the steric congestion around the nitrogen atom of the all-cis cyclobutane skeleton. The use of 9-fluorenylmethylsuccinimidyl carbonate
(FmocONSu) in the presence of $\mathrm{NaHCO}_{3}$ furnished the required $\mathrm{N}$-protected amino acid 7 in $59 \%$ yield. FmocONSu was a superior reagent to $\mathrm{FmocCl}$, which provided 7 in only $13 \%$ yield.

We were able to prepare the methyl ester 8 (62\% yield) from 7 in standard acidic conditions $\left(\mathrm{MeOH} / \mathrm{H}_{2} \mathrm{SO}_{4}\right)$ without inducing lactonization, leaving the primary alcohol as the only free functional group. The carboxamide 9 was also prepared ( $52 \%$ yield) by treatment of 7 with $\mathrm{NH}_{4} \mathrm{HCO}_{3}$ in the presence of $\mathrm{Boc}_{2} \mathrm{O}$ and pyridine. ${ }^{34}$

We have recently studied the base-mediated cis to trans $\mathrm{C} 1$ epimerization of the parent (i.e., bearing no other ring substituents) cyclobutane $\beta$-amino acid, in both methyl ester ${ }^{21 a}$ and carboxamide $^{35}$ derivatized forms. The latter was arguably more efficient, so we applied the appropriate epimerization conditions to carboxamide 9. Treatment of this compound with $25 \%$ aqueous $\mathrm{NaOH}$ solution in refluxing methanol provided the trans- $\beta$-amino acid 10 directly, in $94 \%$ yield (Scheme 3). This final transformation is achieved via three consecutive steps: Fmoc group cleavage, cis to trans epimerization of the intermediate carboxamide, and then hydrolysis of carboxamide to carboxylic acid. The stability of the transcyclobutane $\beta$-amino acid product in the vigorous reaction conditions is noteworthy, and the absence of any products with a cis configuration is remarkable. The three-step cis to trans epimerization procedure (starting and finishing with free $\beta$-amino acid functions) is the shortest such sequence of which we are aware.

\section{Conclusion}

In conclusion, the intramolecular version of the uracilolefin $[2+2]$ photocycloaddition methodology provides a short and efficient entry to 3 -hydroxylated cis-cyclobutane $\beta$-amino acid, which can be transformed into the trans isomer via selective functionalization and an efficient multi-step epimerization process. These procedures are expected to be of use for the preparation of $\beta$-peptides bearing multiple and varied side chain appendages, through further derivatization of the primary alcohol moieties. Work in this respect is in progress.

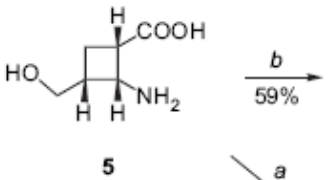

5<smiles>O=C=N[C@H]1C[C@H](CO)C[C@H]1C(=O)O</smiles>

7<smiles>[H][R16]([H])(N[C@H]1C[C@H](CO)[C@H]1C(=O)O)OC(C)(C)C</smiles>
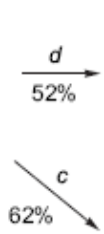

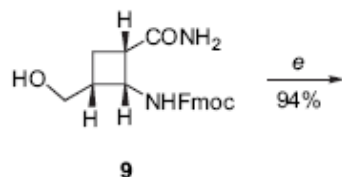<smiles>COC(=O)[C@H]1C[C@H](CO)[C@H]1N=CP=O</smiles>

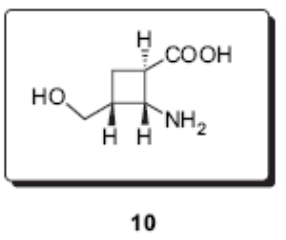

10

Scheme 3. Reagents and conditions: (a) $\mathrm{Boc}_{2} \mathrm{O}, \mathrm{NaOH}$, dioxane/ $\mathrm{H}_{2} \mathrm{O}, 0^{\circ} \mathrm{C}$ to rt, $2.5 \mathrm{~h}$. (b) FmocONSu, $\mathrm{NaHCO}_{3}, \mathrm{acetone}_{2} \mathrm{H}_{2} \mathrm{O}, \mathrm{rt}, 16 \mathrm{~h}$. (c) $\mathrm{MeOH}, \mathrm{H}_{2} \mathrm{SO} \mathrm{O}_{4}$ (cat), $-15^{\circ} \mathrm{C}, 16 \mathrm{~h}$. (d) $\mathrm{Boc}_{2} \mathrm{O}, \mathrm{NH}_{4} \mathrm{HCO}_{3}$, pyridine, dioxane, rt, $5 \mathrm{~h}$. (e) $25 \%$ aq $\mathrm{NaOH}, \mathrm{MeOH}, \Delta, 3 \mathrm{~h}$. 


\section{Experimental}

\subsection{General methods}

Melting points were obtained on a Reichert microscope apparatus. Elemental analyses were performed on a Thermofinnigan EA 1112 instrument. IR spectra were recorded on a Perkin-Elmer Aragon 500 spectrometer; only diagnostic absorbances $\left(\nu_{\max }\right)$ are given. NMR spectra were recorded on a Bruker AC-400 spectrometer operating at $400 \mathrm{MHz}\left({ }^{1} \mathrm{H}\right)$ or $100 \mathrm{MHz}\left({ }^{13} \mathrm{C}\right)$; chemical shifts $(\delta)$ are reported in parts per million, $J$ values are given in hertz. MS data were obtained in $\mathrm{CI}$ mode ( $150 \mathrm{eV}$; vector gas: $\left.\mathrm{CH}_{4}\right)$ on a Hewlett-Packard 5989B instrument, or in positive ESI mode $(3000 \mathrm{~V})$ on a Waters micro Q-TOF instrument.

Flash chromatography was carried out on columns of silica gel $(40-63 \mu \mathrm{m})$; the appropriate eluent is indicated in parentheses. Isolation of amino acids was carried out on columns of Dowex 50X8 ion exchange resin (50-100 mesh) in $\mathrm{H}^{+}$form.

\subsubsection{1-(Allyloxymethyl)uracil (1)}

Uracil $(3.13 \mathrm{~g}, 28 \mathrm{mmol})$ was added to a solution of $\mathrm{N}, \mathrm{O}$ bistrimethylsilylacetamide $(19.7 \mathrm{~g}, 97 \mathrm{mmol})$ in $\mathrm{CH}_{2} \mathrm{Cl}_{2}$ $(280 \mathrm{~mL})$ under argon. The reaction mixture was stirred for $10 \mathrm{~min}$ then chloromethyl allyl ether ${ }^{26}(4.50 \mathrm{~g}, 42 \mathrm{mmol})$ and cesium iodide $(7.20 \mathrm{~g}, 28 \mathrm{mmol})$ were added. The reaction mixture was stirred at $\mathrm{rt}$ for $4 \mathrm{~h}$. The mixture was washed with saturated aqueous $\mathrm{Na}_{2} \mathrm{CO}_{3}$ solution $(200 \mathrm{~mL})$ and then extracted with $\mathrm{CH}_{2} \mathrm{Cl}_{2}(3 \times 150 \mathrm{~mL})$. The combined organic layers were dried over $\mathrm{MgSO}_{4}$, filtered, and then evaporated to yield a yellow powder. This residue was triturated with EtOAc and filtered to give compound 1 as a white powder (4.55 g, 89\%). Mp $117-118^{\circ} \mathrm{C}$; IR (KBr) $\nu_{\max } 1732,1681$, $1828 \mathrm{~cm}^{-1} ;{ }^{1} \mathrm{H}$ NMR $\left(\mathrm{CDCl}_{3}\right) \delta 9.28(\mathrm{~s}, 1 \mathrm{H}), 7.32(\mathrm{~d}, 1 \mathrm{H}$, $J=8 \mathrm{~Hz}), 5.80-5.95(\mathrm{~m}, 1 \mathrm{H}), 5.77(\mathrm{~d}, 1 \mathrm{H}, J=8 \mathrm{~Hz}), 5.22(\mathrm{~d}$, $2 \mathrm{H}, J=10 \mathrm{~Hz}), 5.17(\mathrm{~s}, 2 \mathrm{H}), 4.09(\mathrm{~s}, 2 \mathrm{H}) ;{ }^{13} \mathrm{C} \mathrm{NMR}\left(\mathrm{CDCl}_{3}\right)$ $\delta 163.8,151.2,143.2,133.1,118.4,103.2,76.0,70.5$; MS (CI) $m / z 183[\mathrm{M}+\mathrm{H}]^{+}$. Anal. Calcd for $\mathrm{C}_{8} \mathrm{H}_{10} \mathrm{~N}_{2} \mathrm{O}_{3}: \mathrm{C}$, 52.74; H, 5.53; N, 15.38. Found: C, 52.76; H, 5.59; N, 15.26.

The filtrate was evaporated and the residue was purified by flash chromatography (EtOAc) to furnish 2 as a colorless oil $(0.70 \mathrm{~g}, 10 \%)$. IR $\left(\mathrm{CCl}_{4}\right) \nu_{\max } 1730,1680,1629 \mathrm{~cm}^{-1} ;{ }^{1} \mathrm{H}$ NMR $\left(\mathrm{CDCl}_{3}\right) \delta 7.30(\mathrm{~d}, 1 \mathrm{H}, J=8 \mathrm{~Hz}), 5.80-5.95(\mathrm{~m}, 2 \mathrm{H})$, $5.77(\mathrm{~d}, 1 \mathrm{H}, J=8 \mathrm{~Hz}), 5.22(\mathrm{~d}, 4 \mathrm{H}, J=10 \mathrm{~Hz}), 5.20(\mathrm{~s}, 2 \mathrm{H})$, $5.17(\mathrm{~s}, 2 \mathrm{H}), 4.10(\mathrm{~s}, 2 \mathrm{H}), 4.08(\mathrm{~s}, 2 \mathrm{H}) ;{ }^{13} \mathrm{C} \mathrm{NMR}\left(\mathrm{CDCl}_{3}\right)$ $\delta 163.8,151.3,143.3,133.2,118.4,118.2,103.4,103.2$, 76.0, 75.9, 70.8, 70.5; MS (CI) $m / z 253[\mathrm{M}+\mathrm{H}]^{+}$.

\subsubsection{1,3-Diaza-9-oxa-2,4-dioxotricyclo[5.3.1. $\left.0^{5,11}\right]$ - undecane (3)}

A solution of $1(1.00 \mathrm{~g}, 5.5 \mathrm{mmol})$ in acetone $(510 \mathrm{~mL})$ was irradiated under argon for $4 \mathrm{~h}$ at $\mathrm{rt}$ in an annular reactor equipped with a water cooling system using a $400 \mathrm{~W}$ mediumpressure $\mathrm{Hg}$ vapor lamp fitted with a Pyrex filter. The solvent was then evaporated and the residue was purified by flash chromatography (cyclohexane/EtOAc 3:7) to give 3 as a white powder $(0.89 \mathrm{~g}, 89 \%)$. Mp $167-168^{\circ} \mathrm{C}$; IR (KBr) $\nu_{\max }$
$1694 \mathrm{~cm}^{-1} ;{ }^{1} \mathrm{H}$ NMR $\left(\mathrm{CDCl}_{3}\right) \delta 5.71(\mathrm{~d}, 1 \mathrm{H}, J=11 \mathrm{~Hz})$, $4.23(\mathrm{q}, 1 \mathrm{H}, J=4 \mathrm{~Hz}), 4.13(\mathrm{~d}, 1 \mathrm{H}, J=11 \mathrm{~Hz}), 3.56(\mathrm{~d}, 2 \mathrm{H}$, $J=7 \mathrm{~Hz}), 3.22(\mathrm{~m}, 2 \mathrm{H}), 2.66(\mathrm{~m}, 1 \mathrm{H}), 2.57(\mathrm{q}, 1 \mathrm{H}, J=$ $10 \mathrm{~Hz}), 2.44(\mathrm{~m}, 1 \mathrm{H}) ;{ }^{13} \mathrm{C} \mathrm{NMR}\left(\mathrm{CDCl}_{3}\right) \delta 173.8,153.1$, 71.2, 67.0, 51.2, 33.6, 31.6, 27.2; MS (CI) $\mathrm{m} / \mathrm{z} 183$ $[\mathrm{M}+\mathrm{H}]^{+}$. Anal. Calcd for $\mathrm{C}_{8} \mathrm{H}_{10} \mathrm{~N}_{2} \mathrm{O}_{3}: \mathrm{C}, 52.74 ; \mathrm{H}, 5.53 ; \mathrm{N}$, 15.38. Found: C, 52.37; H, 5.61; N, 14.97 .

\subsubsection{2-Carbamoyl-2-aza-4-oxabicyclo[4.2.0]octane-8- carboxylic acid (4)}

A solution of $3(0.65 \mathrm{~g}, 3.6 \mathrm{mmol})$ in $0.5 \mathrm{M}$ aqueous $\mathrm{NaOH}$ $(23 \mathrm{~mL})$ was stirred at $\mathrm{rt}$ overnight. Cation exchange resin (Bio-Rad AG 50W-X8, $\mathrm{H}^{+}, 20-50$ mesh) was then added until $\mathrm{pH}=4-5$. Filtration and then evaporation of the filtrate left 4 as yellow crystals $(0.55 \mathrm{~g}, 77 \%)$. Mp $142-143^{\circ} \mathrm{C}$; IR ( $\left.\mathrm{KBr}\right)$ $\nu_{\max } 3550,3400,1700,1660 \mathrm{~cm}^{-1} ;{ }^{1} \mathrm{H}$ NMR (DMSO- $d_{6}$ ) $\delta 12.09$ (s, 1H), 6.00 (br s, $2 \mathrm{H}$ ), 5.02 (d, $1 \mathrm{H}, J=8 \mathrm{~Hz}$ ), 4.53 $(\mathrm{t}, 1 \mathrm{H}, J=9 \mathrm{~Hz}), 4.45(\mathrm{~d}, 1 \mathrm{H}, J=8 \mathrm{~Hz}), 3.95(\mathrm{dd}, 1 \mathrm{H}, J=9$ and $11 \mathrm{~Hz}), 3.68(\mathrm{dd}, 1 \mathrm{H}, J=10$ and $8 \mathrm{~Hz}), 3.40(\mathrm{~m}, 1 \mathrm{H})$, $2.72(\mathrm{~m}, 1 \mathrm{H}), 1.96(\mathrm{~m}, 2 \mathrm{H}) ;{ }^{13} \mathrm{C}$ NMR (DMSO- $\left.d_{6}\right) \delta 174.6$, 156.8, 74.0, 68.8, 47.0, 42.2, 31.0, 21.9. HRMS (ESI) Calcd for $\mathrm{C}_{8} \mathrm{H}_{12} \mathrm{~N}_{2} \mathrm{O}_{4} \mathrm{Na}[\mathrm{M}+\mathrm{Na}]^{+}: \mathrm{m} / z$ 223.1817; found 223.1695 .

\subsection{4. cis-2-Amino-3-hydroxymethyl-1-cyclobutane- carboxylic acid (5)}

A solution of $3(1.00 \mathrm{~g}, 5.5 \mathrm{mmol})$ in $1 \mathrm{M}$ aqueous $\mathrm{NaOH}$ (40 mL) was stirred at $80^{\circ} \mathrm{C}$ for $10 \mathrm{~h}$. After cooling, the solution was acidified with $1 \mathrm{M} \mathrm{HCl}(35 \mathrm{~mL})$ and then loaded onto a column of ion exchange resin. Elution with $1 \mathrm{M} \mathrm{NH}_{4} \mathrm{OH}$ solution afforded $\mathbf{5}$ as yellow crystals $(0.80 \mathrm{~g}, 100 \%)$. Mp 153$154{ }^{\circ} \mathrm{C}$; IR (KBr) $\nu_{\max } 3360(\mathrm{br}), 1710 \mathrm{~cm}^{-1} ;{ }^{1} \mathrm{H}$ NMR $\left(\mathrm{D}_{2} \mathrm{O}\right)$ $\delta 3.98(\mathrm{t}, 1 \mathrm{H}, J=8 \mathrm{~Hz}), 3.69(\mathrm{~d}, 2 \mathrm{H}, J=7 \mathrm{~Hz}), 3.21(\mathrm{q}, 1 \mathrm{H}$, $J=9 \mathrm{~Hz}), 2.73(\mathrm{q}, 1 \mathrm{H}, J=8 \mathrm{~Hz}), 2.28(\mathrm{q}, 1 \mathrm{H}, J=8 \mathrm{~Hz}), 1.93$ $(\mathrm{q}, 1 \mathrm{H}, J=8 \mathrm{~Hz}) ;{ }^{13} \mathrm{C}$ NMR $\left(\mathrm{D}_{2} \mathrm{O}\right) \delta 180.1,60.2,48.9,38.2$, 35.2, 24.7. Anal. Calcd for $\mathrm{C}_{6} \mathrm{H}_{11} \mathrm{NO}_{3} \cdot \mathrm{H}_{2} \mathrm{O}: \mathrm{C}, 44.17 ; \mathrm{H}$, 8.03; N, 8.58. Found: C, 43.67; H, 7.68; N, 8.95.

\section{1 .5. cis-2-N-(tert-Butoxycarbonyl)amino-3-hydroxy- methyl-1-cyclobutanecarboxylic acid (6)}

To a solution of $5(0.20 \mathrm{~g}, 1.7 \mathrm{mmol})$ in a mixture of dioxane $(2 \mathrm{~mL})$ and $1 \mathrm{M}$ aqueous $\mathrm{NaOH}(1 \mathrm{~mL})$ was added ditert-butyl dicarbonate $(0.38 \mathrm{~g}, 1.7 \mathrm{mmol})$. The mixture was stirred at $\mathrm{rt}$ for $2.5 \mathrm{~h}$ and then evaporated. Water $(1.6 \mathrm{~mL})$ was added and the solution was acidified with $1 \mathrm{M} \mathrm{HCl}$ until $\mathrm{pH}=2-3$. The mixture was extracted with EtOAc $(3 \times 7 \mathrm{~mL})$ and combined organic layers were dried over $\mathrm{MgSO}_{4}$, filtered, and then evaporated to give 6 as a greenish oil $(0.15 \mathrm{~g}, 45 \%)$. IR $\left(\mathrm{CCl}_{4}\right) \nu_{\max } 3360$ (br), 1740, $1710 \mathrm{~cm}^{-1} ;{ }^{1} \mathrm{H} \mathrm{NMR}\left(\mathrm{CDCl}_{3}\right)$ $\delta 6.25(\mathrm{~s}, 1 \mathrm{H}), 4.42(\mathrm{~s}, 1 \mathrm{H}), 4.23(\mathrm{t}, 1 \mathrm{H}, J=7 \mathrm{~Hz}), 3.94(\mathrm{dd}$, $2 \mathrm{H}), 3.43(\mathrm{~m}, 1 \mathrm{H}), 2.92(\mathrm{~m}, 1 \mathrm{H}), 2.56(\mathrm{~m}, 2 \mathrm{H}), 2.15(\mathrm{~m}$, $2 \mathrm{H}), 1.45(\mathrm{~s}, 9 \mathrm{H}) ;{ }^{13} \mathrm{C} \mathrm{NMR}\left(\mathrm{CDCl}_{3}\right) \delta 175.6,156.1,84.2$, $60.0,48.4,37.5,35.5,26.6,22.5$.

\section{1 .6. cis-2- $N-(9-F l u o r e n y l m e t h y l o x y c a r b o n y l) a m i n o-3-$ \\ hydroxymethyl-1-cyclobutanecarboxylic acid (7)}

To a solution of $5(0.10 \mathrm{~g}, 0.7 \mathrm{mmol})$ and $\mathrm{NaHCO}_{3}(0.12 \mathrm{~g}$, $1.4 \mathrm{mmol})$ in a mixture of water $(7 \mathrm{~mL})$ and acetone $(7 \mathrm{~mL})$ 
was added 9-fluorenylmethylsuccinimidyl carbonate (FmocONSu) $(0.40 \mathrm{~g}, 1.2 \mathrm{mmol})$. The mixture was stirred at it for $16 \mathrm{~h}$ and then acetone was evaporated carefully under reduced pressure. Excess FmocONSu was removed by extraction with EtOAc $(3 \times 10 \mathrm{~mL})$. The residual aqueous layer was acidified with $1 \mathrm{M} \mathrm{HCl}$ until $\mathrm{pH}=1-2$ and then extracted with $\mathrm{CH}_{2} \mathrm{Cl}_{2}(3 \times 10 \mathrm{~mL})$. Combined organic layers were dried over $\mathrm{MgSO}_{4}$, filtered, and then evaporated to give 7 as white crystals $(0.15 \mathrm{~g}, 59 \%)$. Mp $38-39^{\circ} \mathrm{C}$; IR (KBr) $\nu_{\max } 3360$, $1740,1710 \mathrm{~cm}^{-1} ;{ }^{1} \mathrm{H}$ NMR $\left(\mathrm{CDCl}_{3}\right) \delta 7.75(\mathrm{~d}, 2 \mathrm{H}, J=$ $8 \mathrm{~Hz}), 7.56(\mathrm{~d}, 2 \mathrm{H}, J=8 \mathrm{~Hz}), 7.38(\mathrm{t}, 2 \mathrm{H}, J=8 \mathrm{~Hz}), 7.29(\mathrm{t}$, $2 \mathrm{H}, J=8 \mathrm{~Hz}), 6.60(\mathrm{~d}, 1 \mathrm{H}, J=6 \mathrm{~Hz}), 4.67(\mathrm{q}, 1 \mathrm{H}, J=8 \mathrm{~Hz})$, $4.41(\mathrm{~m}, 2 \mathrm{H}), 4.19(\mathrm{t}, 1 \mathrm{H}, J=8 \mathrm{~Hz}), 3.70(\mathrm{~m}, 2 \mathrm{H}), 3.48(\mathrm{q}$, $1 \mathrm{H}, J=8 \mathrm{~Hz}), 2.80(\mathrm{~m}, 1 \mathrm{H}), 2.65(\mathrm{~s}, 1 \mathrm{H}), 2.15(\mathrm{~m}, 2 \mathrm{H}) ;{ }^{13} \mathrm{C}$ NMR $\left(\mathrm{CDCl}_{3}\right) \delta 176.6,157.2,143.7,141.25,127.7,127.1$, 125.2, 120.0, 67.3, 61.35, 49.2, 47.1, 39.9, 39.5, 22.9; MS (ESI) $m / z 390[\mathrm{M}+\mathrm{Na}]^{+}$. Anal. Calcd for $\mathrm{C}_{21} \mathrm{H}_{21} \mathrm{NO}_{5}: \mathrm{C}$, $67.65 ; \mathrm{H}, 5.76$; N, 3.81. Found: C, 67.45; H, 5.95; N, 3.78.

\subsubsection{Methyl cis-2-N-(9-fluorenylmethyloxycarbonyl)- \\ amino-3-hydroxymethyl-1-cyclobutanecarboxylate (8)}

A solution of $7(0.05 \mathrm{~g}, 0.14 \mathrm{mmol})$ in $\mathrm{MeOH}(0.33 \mathrm{~mL})$ was cooled to $-15{ }^{\circ} \mathrm{C}$ and $95 \% \mathrm{H}_{2} \mathrm{SO}_{4}(4 \mu \mathrm{l})$ was added slowly. The mixture was stirred at $-15^{\circ} \mathrm{C}$ for $16 \mathrm{~h}$, warmed to $0{ }^{\circ} \mathrm{C}$, and neutralized by slow addition of a saturated aqueous $\mathrm{NaHCO}_{3}$ solution over $1 \mathrm{~h}$. After removal of solids by filtration, the filtrate was evaporated and the residue was purified by flash chromatography (cyclohexane/EtOAc 6:4) to give 8 as a white powder $(0.03 \mathrm{~g}, 62 \%)$. Mp $85-86{ }^{\circ} \mathrm{C}$; IR $(\mathrm{KBr}) \nu_{\max }$ $3390,2960,1725,1520 \mathrm{~cm}^{-1}$; ${ }^{1} \mathrm{H}$ NMR $\left(\mathrm{CDCl}_{3}\right) \delta 7.77(\mathrm{~d}$, $2 \mathrm{H}, J=8 \mathrm{~Hz}), 7.61(\mathrm{~d}, 2 \mathrm{H}, J=8 \mathrm{~Hz}), 7.39(\mathrm{t}, 2 \mathrm{H}, J=8 \mathrm{~Hz})$, $7.31(\mathrm{t}, 2 \mathrm{H}, J=8 \mathrm{~Hz}), 6.55(\mathrm{~d}, 1 \mathrm{H}, J=6 \mathrm{~Hz}), 4.61(\mathrm{q}, 1 \mathrm{H}, J=$ $8 \mathrm{~Hz}), 4.37$ (m, 2H), $4.21(\mathrm{t}, 1 \mathrm{H}, J=7 \mathrm{~Hz}), 3.70(\mathrm{~s}, 1 \mathrm{H}), 3.60$ $(\mathrm{m}, 2 \mathrm{H}), 3.47(\mathrm{q}, 1 \mathrm{H}, J=8 \mathrm{~Hz}), 2.92(\mathrm{~m}, 1 \mathrm{H}), 2.79(\mathrm{~s}, 1 \mathrm{H})$, $2.20(\mathrm{~m}, 2 \mathrm{H}) ;{ }^{13} \mathrm{C} \mathrm{NMR}\left(\mathrm{CDCl}_{3}\right) \delta 173.8,156.9,143.9$, $141.3,127.7,127.1,125.1,120.0,67.2,61.5,52.0,49.6$, 47.2, 46.8, 39.6, 23.2; MS (ESI) $\mathrm{m} / \mathrm{z} 404[\mathrm{M}+\mathrm{Na}]^{+}$. Anal. Calcd for $\mathrm{C}_{22} \mathrm{H}_{23} \mathrm{NO}_{5}$ : C, 69.28; H, 6.08; N, 3.67. Found: C, $69.52 ; \mathrm{H}, 5.60 ; \mathrm{N}, 3.42$.

\subsection{8. cis-2-N-(9-Fluorenylmethyloxycarbonyl)amino-3- \\ hydroxymethyl-1-cyclobutanecarboxamide (9)}

To a solution of $7(0.07 \mathrm{~g}, 0.19 \mathrm{mmol})$ in dioxane $(4 \mathrm{~mL})$ were added di-tert-butyl dicarbonate $(0.06 \mathrm{~g}, 0.27 \mathrm{mmol})$, ammonium hydrogen carbonate $(0.05 \mathrm{~g}, 0.57 \mathrm{mmol})$, and pyridine $(0.03 \mathrm{~g}, 0.38 \mathrm{mmol})$. The mixture was stirred at $\mathrm{rt}$ for $5 \mathrm{~h}$ and then water $(3 \mathrm{~mL})$ was added. This mixture was extracted with EtOAc $(3 \times 3 \mathrm{~mL})$ and combined organic layers were dried over $\mathrm{MgSO}_{4}$, filtered, and then evaporated. The residue was purified by flash chromatography (cyclohexane/ EtOAc 6:4) to give 9 as a yellow oil $(0.04 \mathrm{~g}, 52 \%)$. IR $\left(\mathrm{CCl}_{4}\right) \nu_{\max } 3360,1740,1700 \mathrm{~cm}^{-1} ;{ }^{1} \mathrm{H} \mathrm{NMR}\left(\mathrm{CDCl}_{3}\right)$ $\delta 7.76(\mathrm{~d}, 2 \mathrm{H}, J=8 \mathrm{~Hz}), 7.57(\mathrm{~d}, 2 \mathrm{H}, J=8 \mathrm{~Hz}), 7.40(\mathrm{t}, 2 \mathrm{H}$, $J=8 \mathrm{~Hz}), 7.31(\mathrm{t}, 2 \mathrm{H}, J=8 \mathrm{~Hz}), 5.40(\mathrm{~d}, 1 \mathrm{H}, J=6 \mathrm{~Hz}), 5.08$ $(\mathrm{m}, 1 \mathrm{H}), 4.58(\mathrm{~m}, 1 \mathrm{H}), 4.46(\mathrm{~m}, 3 \mathrm{H}), 4.41(\mathrm{~d}, 2 \mathrm{H}, J=6 \mathrm{~Hz})$, $4.19(\mathrm{t}, 1 \mathrm{H}, J=7 \mathrm{~Hz}), 3.26(\mathrm{~m}, 1 \mathrm{H}), 2.93(\mathrm{~m}, 1 \mathrm{H}), 2.03(\mathrm{~m}$, $1 \mathrm{H}), 1.73(\mathrm{~m}, 1 \mathrm{H}) ;{ }^{13} \mathrm{C} \mathrm{NMR}\left(\mathrm{CDCl}_{3}\right) \delta 172.2,155.5,143.6$,
$141.2,127.7,127.0,124.9,119.9,68.3,67.0,47.0,46.9$, $46.8,38.3,23.0$.

\subsection{9. trans-2-Amino-3-hydroxymethyl-1-cyclobutane- carboxylic acid (10)}

To a stirred solution of $9(0.04 \mathrm{~g}, 0.09 \mathrm{mmol})$ in $\mathrm{MeOH}$ $(1 \mathrm{~mL})$ was added $25 \%$ aqueous $\mathrm{NaOH}(5 \mathrm{~mL}, 6.3 \mathrm{mmol})$. The mixture was stirred at reflux for $3 \mathrm{~h}, \mathrm{MeOH}$ was evaporated carefully under reduced pressure, and the residual aqueous phase was extracted with $\mathrm{CH}_{2} \mathrm{Cl}_{2}(3 \times 5 \mathrm{~mL})$. The aqueous layer was then neutralized at $-5^{\circ} \mathrm{C}$ with $1 \mathrm{M} \mathrm{HCl}$ and then loaded onto a column of ion exchange resin. Elution with $1 \mathrm{M} \mathrm{NH}_{4} \mathrm{OH}$ solution afforded 10 as yellow crystals $(0.01 \mathrm{~g}$, $94 \%)$. Mp $172-173^{\circ} \mathrm{C}$; IR (KBr) $\nu_{\max } 3360,1710 \mathrm{~cm}^{-1} ;{ }^{1} \mathrm{H}$ NMR $\left(\mathrm{D}_{2} \mathrm{O}\right) \delta 3.72(\mathrm{~m}, 2 \mathrm{H}), 3.56(\mathrm{~m}, 2 \mathrm{H}), 3.10(\mathrm{q}, 1 \mathrm{H}$, $J=8 \mathrm{~Hz}), 2.50(\mathrm{~m}, 1 \mathrm{H}), 2.07(\mathrm{q}, 1 \mathrm{H}, J=9 \mathrm{~Hz}), 1.96(\mathrm{q}, 1 \mathrm{H}$, $J=10 \mathrm{~Hz}) ;{ }^{13} \mathrm{C}$ NMR $\left(\mathrm{D}_{2} \mathrm{O}\right) \delta 173.8,60.9,50.6,43.0,35.8$, 24.8 .

\section{Acknowledgements}

We thank undergraduate students $\mathrm{M}$. Nevoso and N. Rodrigues for carrying out some experiments.

\section{References and notes}

1. (a) Steer, D. L.; Lew, R. A.; Perlmutter, P.; Smith, A. I.; Aguilar, M.-I. Curr. Med. Chem. 2002, 9, 811-822; (b) Schreiber, J. V.; Frackenpohl, J.; Moser, F.; Fleishmann, T.; Kohler, H.-P. E.; Seebach, D. ChemBioChem 2002, 3, 424-432; (c) Cheng, R. P.; Gellman, S. H.; Degrado, W. F. Chem. Rev. 2001, 101, 3219-3232.

2. (a) Enantioselective Synthesis of $\beta$-Amino Acids, 2nd ed.; Juaristi, E., Soloshonok, V. A., Eds.; Wiley-VCH: Weinheim, 2005; (b) Liu, M.; Sibi, M. P. Tetrahedron 2002, 58, 7991-8035; (c) Abele, S.; Seebach, D. Eur. J. Org. Chem. 2000, 1-15; (d) Abdel-Magid, A. F.; Cohen, J. H.; Maryanoff, C. A. Curr. Med. Chem. 1999, 6, 955-969; (e) Juaristi, E.; López-Ruiz, H. Curr. Med.Chem. 1999, 6, 983-1004; (f) Cardillo, G.; Tomasini, C. Chem. Sac. Rev. 1996, 117-128.

3. General reviews: (a) Fülop, F. Chem. Rev. 2001, 101, 2181-2204; (b) Kuhl, A.; Hahn, M. G.; Dumić, M.; Mittendorf, J. Amino Acids 2005, $29,89-100$.

4. Leading references on the folding structures adopted by alicyclic $\beta$-amino acid oligopeptides: (a) De Pol, S.; Zom, C.; Klein, C. D.; Zerbe, O.; Reiser, O. Angew. Chem., Int. Ed. 2004, 43, 511-514; (b) Martinek, T. A.; Tóth, G. K.; Vass, E.; Hollósi, M.; Fülöp, F. Angew. Chem., Int. Ed. 2002, 41, 1718-1721; (c) Hetényi, A.; Mándity, I. M.; Martinek, T. A.; Tóth, G. K.; Fülöp, F. J. Am. Chem. Soc. 2005, 127, 547-553; (d) Hayen, A.; Schmitt, M. A.; Ngassa, F. N.; Thomasson, K. A.; Gellman, S. H. Angew. Chem., Int. Ed. 2004, 43, 505-510; (e) Appella, D. H.; Christianson, L. A.; Karle, I. L.; Powell, D. R.; Gellman, S. H. J. Am. Chem. Soc. 1999, 121, 6206-6212; (f) Barchi, J. J., Jr.; Huang, X.; Appella, D. H.; Christianson, L. A.; Durell, S. R.; Gellman, S. H. J. Am. Chem. Soc. 2000, 122, 2711-2718; (g) Appella, D. H.; Christianson, L. A.; Klein, D. A.; Richards, M. R.; Powell, D. R.; Gellman, S. H. J. Am. Chem. Soc. 1999, 121, 7574-7581; (h) North, M. J. J. Peptide Sci. 2000, 6, 301-313.

5. (a) Fülop, F.; Palkó, M.; Forró, E.; Dervarics, M.; Martinek, T. A.; Sillanpää, R. Eur. J. Org. Chem. 2005, 3214-3220; (b) Szakonyi, Z. Gyónfalvi, S.; Forró, E.; Hetényi, A.; De Kimpe, N.; Fülop, F. Eur. J. Org. Chem. 2005, 4017-4023; (c) Wipf, P.; Wang, X. Tetrahedron Lett. 2000, 41, 8747-8751; (d) Bolm, C.; Schiffers, I.; Dinter, C. L.; Defrère, L.; Gerlach, A.; Raabe, G. Synthesis 2001, 1719-1730; (e) Barluenga, J.; Aznar, F.; Ribas, C.; Valdés, C. J. Org. Chem. 1998, 63, 10052-10056. 
6. (a) Fülop, F. Stud. Nat. Prod. Chem. 2000, 22, 273-306; (b) Woll, M. G.; Fisk, J. D.; LePlae, P. R.; Gellman, S. H. J. Am. Chem. Soc. 2002, 124, 12447-12452; (c) Soengas, R. G.; Pampín, M. B.; Estévez, J. C.; Estévez, R. J. Tetrahedron: Asymmetry 2005, 16, 205-211; (d) Mittendorf, J.; Kunisch, F.; Matzke, M.; Militzer, H.-C.; Schmidt, A.; Schönfeld, W. Bioorg. Med. Chem. Lett. 2003, 13, 433-436.

7. (a) Gnad, F.; Reiser, O. Chem. Rev. 2003, 103, 1603-1623; (b) Miller, J. A.; Hennessy, E. J.; Marchall, W. J.; Scialdone, M. A.; Nguyen, S. T. J. Org. Chem. 2003, 68, 7884-7886; (c) Hibbs, D. E.; Hursthouse, M. B.; Jones, I. G.; Jones, W.; Malik, K. M. A.; North, M. Tetrahedron $1997,53,17417-17424$.

8. (a) Hibbs, D. E.; Hursthouse, M. B.; Jones, I. G.; Jones, W.; Malik, K. M. A.; North, M. J. Org. Chem. 1998, 63, 1496-1504; (b) Kawahata, N. H.; Goodman, M. Tetrahedron Lett. 1999, 40, 2271-2274; (c) Fülop, F.; Palkó, M.; Kámán, J.; Lázár, L.; Sillanpää, R. Tetrahedron: Asymmetry 2000, 11, 4179-4187; (d) Gyónfalvi, S.; Szakonyi, Z.; Fülop, F. Tetrahedron: Asymmetry 2003, 14, 3965-3972; (e) Kiss, L.; Forró, E.; Bernáth, G.; Fülop, F. Synthesis 2005, 1265-1268; (f) Gyarmati, Z. C.; Liljeblad, A.; Rintola, M.; Bernáth, G.; Kanerva, L. T. Tetrahedron: Asymmetry 2003, 14, 3805-3814; (g) Tanaka, M.; Oba, M.; Ichiki, T.; Suemune, H. Chem. Pharm. Bull. 2001, 49, 1178-1181; (h) Langer, O.; Kählig, H.; Zierler-Gould, K.; Bats, J. W.; Mulzer, J. J. Org. Chem. 2002, 67 , $6878-6883$.

9. Recent review of cyclobutane $\beta$-amino acids: Ortuño, R. M.; Moglioni, A. G.; Moltrasio, G. Y. Curr. Org. Chem. 2005, 9, 237-259.

10. In the only studies described to date, peptides containing the parent ciscyclobutane $\beta$-amino acid show strong structuring tendencies: (a) Rúa, F.; Boussert, S.; Parella, T.; Díez-Pérez, I.; Branchadell, V.; Giralt, E.; Ortuño, R. M. Org. Lett. 2007, 9, 3643-3645; (b) Izquierdo, S.; Rúa, F.; Sbai, A.; Parella, T.; Álvarez-Larena, Á.; Branchadell, V.; Ortuño, R. M. J. Org. Chem. 2005, 70, 7963-7971; (c) Izquierdo, S.; Kogan, M. J.; Parella, T.; Moglioni, A. G.; Branchadell, V.; Giralt, E.; Ortuño, R. M. J. Org. Chem. 2004, 69, 5093-5099.

11. Kennewell, P. D.; Matharu, S. S.; Taylor, J. B.; Westwood, R.; Sammes, P. G. J. Chem. Soc., Perkin Trans. 1 1982, 2563-2570.

12. (a) Martín-Vilà, M.; Muray, E.; Aguado, G. P.; Alvarez-Larena, A.; Branchadell, V.; Minguillón, C.; Giralt, E.; Ortuño, R. M. Tetrahedron. Asymmetry 2000, 11, 3569-3584; (b) Martín-Vilà, M.; Minguillón, C.; Ortuño, R. M. Tetrahedron: Asymmetry 1998, 9, 4291-4294.

13. Bolm, C.; Schiffers, I.; Atodiresei, I.; Hackenberger, C. P. R. Tetrahedron: Asymmetry 2003, 14, 3455-3467.

14. (a) Cannon, J. G.; Rege, A. B.; Gruen, T. L.; Long, J. P. J. Med. Chem. 1972, 15, 71-75; (b) Shroff, C. C.; Stewart, W. S.; Uhm, S. J.; Wheeler, J. W. J. Org. Chem. 1971, 36, 3356-3361.

15. (a) Mitsudo, T.; Zhang, S.-W.; Satake, N.; Kondo, T.; Watanabe, Y Tetrahedron Lett. 1992, 33, 5533-5536; (b) Stoermer, R.; Schenk, F; Pansegrau, E. Ber. Dtsch. Chem. Ges. 1927, 60, 2566-2591.

16. Yuan, P.; Driscoll, M. R.; Raymond, S. J.; Hansen, D. E.; Blatchly, R. A. Tetrahedron Lett. 1994, 35, 6195-6198.

17. Brannock, K. C.; Bell, A.; Burpitt, R. D.; Kelly, C. A. J. Org. Chem. 1964, $29,801-812$.
18. (a) Hayashi, Y.; Otaka, K.; Saito, N.; Narasaka, K. Bull. Chem. Soc. Jpn. 1991, 64, 2122-2127; (b) Kitayama, T.; Kawauchi, T.; Ueda, N.; Kniep, C. S.; Shin, W. S.; Padias, A. B.; Hall, H. K., Jr. Macromolecules 2002, 35 , 1591-1598; (c) Sheldrake, H. M.; Wallace, T. W.; Wilson, C. P. Org. Lett. 2005, 7, 4233-4236.

19. Katagiri, N.; Sato, H.; Kaneko, C. Chem. Pharm. Bull. 1990, 38, 288290.

20. Aitken, D. J.; Gauzy, C.; Pereira, E. Tetrahedron Lett. 2002, 43, 61776179 .

21. (a) Fernandes, C.; Gauzy, C.; Yang, Y.; Pereira, E.; Faure, S.; Aitken, D. J. Synthesis 2007, 2222-2232; (b) Gauzy, C.; Pereira, E.; Faure, S.; Aitken, D. J. Tetrahedron Lett. 2004, 45, 7095-7097.

22. Gauzy, C.; Saby, B.; Pereira, E.; Faure, S.; Aitken, D. J. Synlett 2006, 1394-1398.

23. (a) Crimmins, M. T.; Reinhold, T. L. Org. React. 1993, 44, 297-588; (b) Crimmins, M. T. Comprehensive Organic Synthesis; Trost, B. M., Ed.; Pergamon: Oxford, 1991; Vol. 5, pp 123-150.

24. (a) Ahn, C. I.; Choi, H. Y.; Hahn, B. S. Heterocycles 1990, 31, $1737-$ 1743; (b) Kavanagh, P. V.; Kelly, J. M.; McMurry, T. B. H.; James, J. P. Chem. Commun. 1993, 231-232; (c) Gimenez-Amau, E.; Mabic, S.; Lepoittevin, J.-P. Chem. Res. Toxicol. 1995, 8, 22-26; (d) Agócs, A.; Batta, G.; Jekô, J.; Herczegh, P. Tetrahedron: Asymmetry 2004, 15, 283-287.

25. (a) Ozerov, A. A.; Novikov, M. S.; Brel, A. K.; Andreeva, O. T.; Vladyko, G. V.; Boreko, E. I.; Korobchenko, L. V.; Vervetchenko, S. G. Khim.-Farm. Zh. 1991, 25, 44-47; Chem. Abstr. 1991, 115, 208452; (b) Ozerov, A. A.; Brel, A. K.; Ozerova, T. P.; Boreko, E. I.; Korobchenko, L. V.; Vladyko, G. V. Khim.-Farm. Zh. 1993, 27, 42-43; Chem. Abstr. 1993, 120, 324096.

26. Kawasaki, T.; Kimachi, T. Tetrahedron 1999, 55, 6847-6862.

27. Petersen, L.; Jessen, C. H.; Pederson, E. B.; Nielsen, C. Org. Biomol. Chem. 2003, 1, 3541-3545.

28. Reactions in these conditions were most efficient on about $1 \mathrm{~g}$ scale. On runs using $3-4 \mathrm{~g}$ starting material, the isolated yield of $\mathbf{2}$ was a bit lower (around 75\%).

29. (a) Sainsbury, M. Comprehensive Heteracyclic Chemistry II; Boulton, A. J., Ed.; Elsevier: Oxford, 1996; Vol. 6, pp 301-348; (b) Beak, P.; Yum, E. K. J. Org. Chem. 1993, 58, 823-824; (c) Coulton, S.; Southgate, S. J. Chem. Sac., Perkin Trans. 1 1992, 961-967; (d) Hirai, H.; Sawada, K.; Yamada, A.; Aratani, M.; Hashimoto, M. Heterocycles 1985, 23 , 2277-2287; (e) Meyers, A. I.; Nabeya, A.; Adickes, H. W.; Politzer, I. R. J. Am. Chem. Soc. 1969, 91, 763-764 and the following papers.

30. Kundu, N. G.; Khatri, S. G. Synthesis 1985, 323-324.

31. Kundu, N. G.; Hertzberg, R. P.; Hannon, S. J. Tetrahedron Lett. 1980, 21, 1109-1112.

32. Rachina, V.; Blagoeva, I. Synthesis 1982, 967-968.

33. Aitken, D. J.; Gauzy, C.; Pereira, E. Tetrahedron Lett. 2004, 45, 23592361.

34. Chulin, A. N.; Rodionov, I. L.; Baidakova, L. K.; Rodionova, L. N.; Balashova, T. A.; Ivanov, V. T. J. Peptide Sci. 2005, 11, 175-186.

35. Fernandes, C.; Pereira, E.; Faure, S.; Aitken, D. J. In preparation. 